\title{
Extending Postharvest Longevity and Improving Quality of Strawberry (Fragaria Ananasa Duch Cv. 'Gaviota') Fruit by Postharvest Salicylic Acid
} Treatment

\author{
Mahsa Geransayeh (Corresponding author) \\ Department of Horticulture, College of Agriculture and Natural Resources \\ Science and Research Branch, Islamic Azad University Tehran, Iran \\ E-mail: m.geransayeh@yahoo.com \\ Sadegh Sepahvand, Vahid Abdossi \\ Department of Horticulture, College of Agriculture and Natural Resources \\ Science and Research Branch, Islamic Azad University Tehran, Iran
}

Received: March 20, 2015 Accepted: April 4, 2015

doi:10.5296/jas.v3i2.7274 URL: http://dx.doi.org/10.5296/jas.v3i2.7274

\begin{abstract}
Strawberries are an extremely perishable fruit mainly due to their soft texture and sensitivity to fungal infection. Postharvest application of conventional fungicides to fruits is prohibited. As an alternative to fungicides, salicylic acid has been found to enhance disease resistance of horticultural crops. In order to study the effect of salicylic acid as a phenolic compound on the postharvest durability and quality characteristics of strawberry fruit. 'Gaviota' strawberries were treated with SA at different concentrations $\left(0,25,50\right.$ and $\left.100 \mu \mathrm{LL}^{-1}\right)$, then stored for 12 days at $4{ }^{\circ} \mathrm{C}$ and $75 \% \mathrm{RH}$ in darkness. Two different methods were applied (spray SA on fruits and paper disk method). Quality attributes such as weight loss, pH, TA, TSS, vitamin C, anthocyanin, calcium, pectin, CAT, POD, PG activity, decay percentage and sensory analyses evaluated every 3 days during storage. Results showed that, treated fruits with SA had lower weight loss, $\mathrm{pH}$, TSS, POD, PG, decay and higher TA, vitamin C, anthocyanin, calcium, pectin, CAT and fruit quality compared with controls. Between two methods of treatment, paper disk method had higher effect on fruit decay and quality compared to spray method and as a general result, caused longer storability.
\end{abstract}


Keywords: Postharvest durability, Salicylic acid, Enzyme activity, Fruit quality.

\section{Introduction}

Strawberry fruit quality decrease rapidly after harvesting, due to the high metabolic activity (Lolaei et al., 2012). Because of the harmful effects of chemical fungicides on human health and the environment, developing safe and nonchemical compounds are highly needed (Mandal et al., 2009). Salicylic acid or ortho-hydroxybenzoic acid is one of the effective natural phenolic compounds has been extensively used for quality improvement in a number of crops and as a plant growth regulator can enhance disease resistance of plants (Pen and Jiang, 2006). SA is considered as generally recognized as safe (GRAS) (Hooper and Cassidy, 2006). Lolaei et al. (2012) were studied the effect of SA as postharvest treatment on the strawberry fruit quality. Treated fruits had higher TA, vitamin $\mathrm{C}$ and redness and less weight loss, decay than the control and delays the ripening of strawberry fruit. Application of SA at nontoxic concentrations to susceptible fruits and vegetables could enhance resistance to pathogens and control postharvest decay of crops (Asghari et al., 2009; Asghari et al., 2007; Babalar et al., 2007). Methyl salicylate (MeSA) vapor was significantly affected postharvest decay of Hayward kiwifruit during storage period (Soleimani Aghdam et al., 2009). Treatment of pear fruit in $1 \mathrm{mmol} \mathrm{L}^{-1} \mathrm{SA}$ solution effectively controlled fruit decay during 5 months of storage (Asghari et al., 2007). Postharvest treatment of strawberry fruits with 1 and $2 \mathrm{mmolL}^{-1}$ significantly controlled fruit decay and increased shelf life of fruit (Babalar et al., 2007). Treatment of table grapes with SA before coating with chitosan effectively enhanced the efficacy of coating and decreased fruit total decay (Asghari et al., 2009). Postharvest treatment of grapes with SA had a positive effect on hardiness, appearance of fruit and controlled fungal infections compared with control (Duan et al., 2007). The application of 2 $\mathrm{m} \mu$ SA effectively increased antioxidant compounds, ascorbic acid content and TSS and prevented fungal infection of strawberries (Amborabe et al., 2002) and softening of bananas and kiwifruits at maturity stage (Srivastava and Dwivedi, 2000; Wang and Zheng, 2001). SA significantly reduced the quality loss in peaches (Wang et al., 2006), tomato (Ding et al., 2001), sweet peppers (Fung et al., 2004), and loquat fruits (Cai et al., 2005). The aim of the present study was to evaluate the effects of postharvest salicylic acid application on quality parameters during cold storage and storage life of strawberry fruit.

\section{Materials and Methods}

\subsection{Plant Material}

strawberries (Fragaria ananassa L.), cv. 'Gaviota' were harvested in the morning randomly from a commercial greenhouse located in Hashtgerd, Karaj, Iran at commercial maturity stage and transported to the laboratory where undamaged fruits at the same ripening stage ( $80 \%$ of the skin red) were selected. Samples were taken every 3 days up to the end of experiment (12 days) and fruits were evaluated at each sampling time after keeping them a day at room temperature.

\subsection{SA Treatment}

Treatments with SA were performed by dissolving the requisite amounts of SA $(0,25,50$ and 
$100 \mu 1 \mathrm{~L}^{-1}$ ) in ethanol. Two different methods were applied (spray SA on fruits and paper disk method). SA sprayed on fruits and spotted onto filter paper at the final concentration of control, 25, 50 and $100 \mu \mathrm{lL}^{-1}$ then air dried. Each treatment was replicated three times with $150 \mathrm{~g}$ fruits per replicate. All packages were stored at $4{ }^{\circ} \mathrm{C}$ and $75 \% \mathrm{RH}$ in darkness for 12 days. Measurements were made at room temperature every 3 days. Quality attributes such as weight loss, $\mathrm{pH}$, TA, TSS, vitamin C, anthocyanin, calcium, pectin, CAT, POD, PG activity, decay percentage and sensory analyses evaluated during storage.

\subsection{Weight Loss Percentage}

The effect of SA exposure on fruit weight loss was also investigated. Weight of individual fruits was recorded at the beginning of harvest and different sampling times and expressed as percentage of original weight (Saini et al., 2006).

\section{$2.4 \mathrm{pH}$}

pH was measured using a pH meter Metrohm Lab 827 (Saini et al., 2006).

\subsection{Titratable Acidity (TA)}

Titrable acidity was measured using titration method. To do that, $5 \mathrm{~mL}$ fruit juice was added to $25 \mathrm{~mL}$ distilled water plus two drops of phenolphthalein and titrated with $0.1 \mathrm{~N} \mathrm{NaOH}$ up to $\mathrm{pH}$ 8.1. The results were expressed as gram of citric acid per $100 \mathrm{~g}$ fresh weight (AOAC, 1990).

\subsection{Total Soluble Solids (TSS)}

TSS was determined using ATAGO-ATC-20E (Japan) refractometer at $20{ }^{\circ} \mathrm{C}$ and expressed as ${ }^{\circ}$ Brix.

\subsection{Vitamin C Assay}

The content of vitamin $\mathrm{C}$ was determined using indophenol procedure. $10 \mathrm{ml}$ of samples were filtrated and titrated against sodium 2, 6-dichlorophenol indophenol dye to a faint pink color which persisted for 5-10 seconds. It was expressed as mg vitamin C/100g fruit weight (Titer $\times$ dye equiv. $\times$ dilution $\times 100 /$ Wt. of sample) (Saini et al., 2006).

\subsection{Anthocyanin Assay}

Total anthocyanin content of strawberry extract was measured using the $\mathrm{pH}$ differential method. Absorbance was measured at 510 and $700 \mathrm{~nm}$, respectively, in different buffers at $\mathrm{pH}$ 1.0 and 4.5, using $\mathrm{A}=$ [(A510-A700) $\mathrm{pH} 1.0$ (A510-A700) $\mathrm{pH} 4.5]$ with a molar extinction coefficient for cyanidin-3-glucoside of 29600. Results were expressed as milligrams of cyanidin-3-glucoside (C3G) equivalents per $100 \mathrm{~g}$ of fresh weight (Cheng \& Breen, 1991).

\subsection{Calcium Content}

Calcium was precipitated as calcium oxalate. The precipitate was dissolved in hot dilute sulfuric acid and titrated with standard potassium permanganate. $1 \mathrm{ml} .0 .1 \mathrm{~N} \mathrm{KMnO}_{4}=0.002$ gm. Calcium (Ruck, 1969). 


\subsection{Pectin Content}

Pectin was precipitated as calcium pectate from an acid solution by the addition of calcium chloride. The calcium pectate precipitate was washed with water until chloride-free, then dried and weighed. Ca pectate $(\%)=$ wt. of Ca pectatex $100 /$ wt. of sample (Ruck, 1969).

\subsection{Peroxidase Activity}

POD activity was assayed Spectrophotometrically with guaiacol by measuring an increase in absorbance at $470 \mathrm{~nm}(\varepsilon=26.6 \mathrm{mM}-1 \mathrm{~cm}-1)$ according to Maehly and Chance (1954). The mixture of $0.5 \mathrm{~cm} 3$ of the enzyme extract, $0.5 \mathrm{~cm} 3$ of $50 \mathrm{mM}$ acetate buffer (pH 5.6), $0.5 \mathrm{~cm} 3$ of $20 \mathrm{Mm}$ guaiacol and $0.5 \mathrm{~cm} 3$ of $60 \mathrm{mM} \mathrm{H} \mathrm{H}_{2} \mathrm{O}_{2}$ was used. The enzyme activity was expressed in units (mmol tetraguaiacol min-1) per $\mathrm{g}$ fresh weight.

\subsection{Catalase Activity}

CAT activity was determined at $25^{\circ} \mathrm{C}$ according to Aebi (Aebi, 1984). The reaction mixture contained $40 \mathrm{mM}$ phosphate buffer $\mathrm{pH} 7.0$ and $0.1 \mathrm{ml}$ pure enzyme in a total volume of $3 \mathrm{ml}$. CAT activity was estimated by decreased in absorbance of $\mathrm{H}_{2} \mathrm{O}_{2}$ at $240 \mathrm{~nm}$.

\subsection{Polygalacturonase Activity}

PG activity was determined by measuring reducing groups released from sodium polypectate, using D-galacturonic acid as the standard. The assay medium reagents were $0.2 \mathrm{M}$ acetate buffer, $\mathrm{pH} 4.5$ to the amount $0.2 \mathrm{ml}$, and $1 \%$ polygalacturonic acid in $0.05 \mathrm{M}$ acetate buffer solution $\mathrm{pH} 4.5$ to the amount $0.3 \mathrm{ml}$. One $\mathrm{ml}$ of enzyme solution and distilled water was added. The reaction started by adding the enzyme, and it was then left for $30 \mathrm{~min}$ at $37^{\circ} \mathrm{C}$, after which the reaction was stopped by adding 3,5-dinitrosalicylic acid (DNS). The solution was then boiled in water for $5 \mathrm{~min}$, after which it was diluted and absorbance measured at a wavelength of $520 \mathrm{~nm}$, using galacturonic acid $(0-1 \mathrm{mg} / \mathrm{ml})$ as the standard solution (Miller, 1959). One unit of polygalacturonase activity (U/g) was defined as the amount of enzyme which released one mol of galacturonic acid per minute per gram of substrate.

\subsection{Decay Percentage}

Percent of decay was scored on a 1-5 scale, where: $1=$ intact fruit, $2=$ more than $5 \%$ Decay, $3=$ between 5-20 \% decay, $4=$ between 20-50 \% decay, 5= more than 50\% decay (Ayala-Zavala et al., 2005).

\subsection{Sensory Evaluation}

Sensory analyses to compare the quality of treated and control fruits were carried out by a 10 trained adults aged 25-40 years. It was about aroma, taste, firmness, appearance and texture. Panelists scored fruits between1-10. Ten being the best total quality and 1 being the worst (Hernandez-Munoz et al., 2008). Samples were scored for overall quality by using an interval hedonic scale. Assessments were continued until fruits condition were considered unacceptable. 


\section{MInstitute"}

\subsection{Statistical Analysis}

Statistical analysis of the data obtained in the present study was carried out using split factorial method in a completely randomized design layout with 3 replications. Data obtained were subjected to analysis of variance (ANOVA).

\section{Results and Discussion}

\subsection{Weight Loss}

No significant differences in weight loss were observed among all of the SA treatment concentrations. SA treatment decreased weight loss of strawberries during storage for 12 days compared with controls. Between two methods of treatments fruits that treated with paper disk method (Figure 1) had more weight loss than spray method (Figure 2). SA can also decrease the respiration rate and fruit weight loss (Zheng and Zhang, 2004). Lolaei et al. (2012) reported that strawberry fruits dipped by SA had less weight loss and the greatest fruit weight loss was calculated in plants treated with $7 \mathrm{mM}$. Besides, our results are in agreement with Garcia et al. (1995) who found similar results in strawberry fruits cv. 'Tudla' and Soleimani Aghdam et al. (2011) who stated that weight loss of the kiwifruit was significantly decreased when they were treated by methyl salicylate (MeSA). Weight loss in fruit decreased with increasing of MeSA concentration. Decrease in fruit metabolic activities results to decrease in fruit water content, weight loss, carbohydrate depletion rate and delay fruit senescence process (Wills et al., 1998). Kazemi et al. (2011) reported that maximum weight loss occurred in control apples while lowest loss was recorded in $3 \mathrm{mM}$ SA treatment. SA also decreases in respiration rate and fruit weight losses by closing stoma (Zheng \& Zhang, 2004).

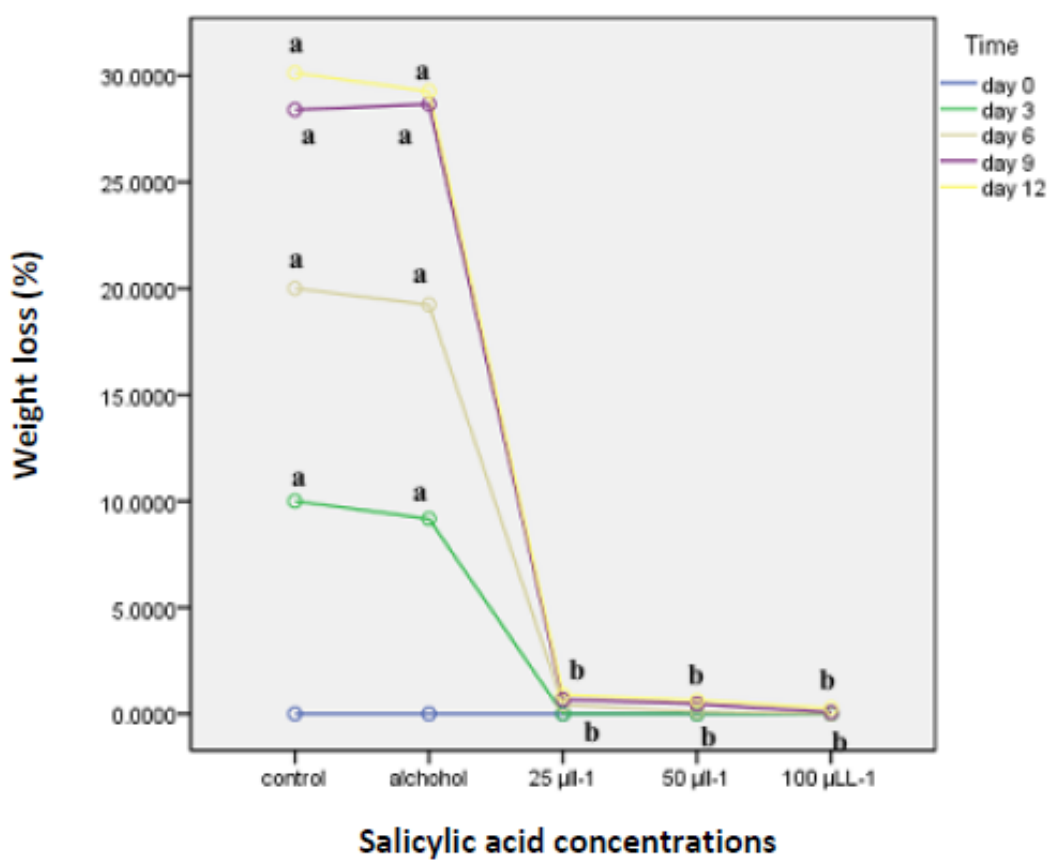

Figure 1. The effect of salicylic acid treatment on weight loss of strawberry fruit in paper disk method. 


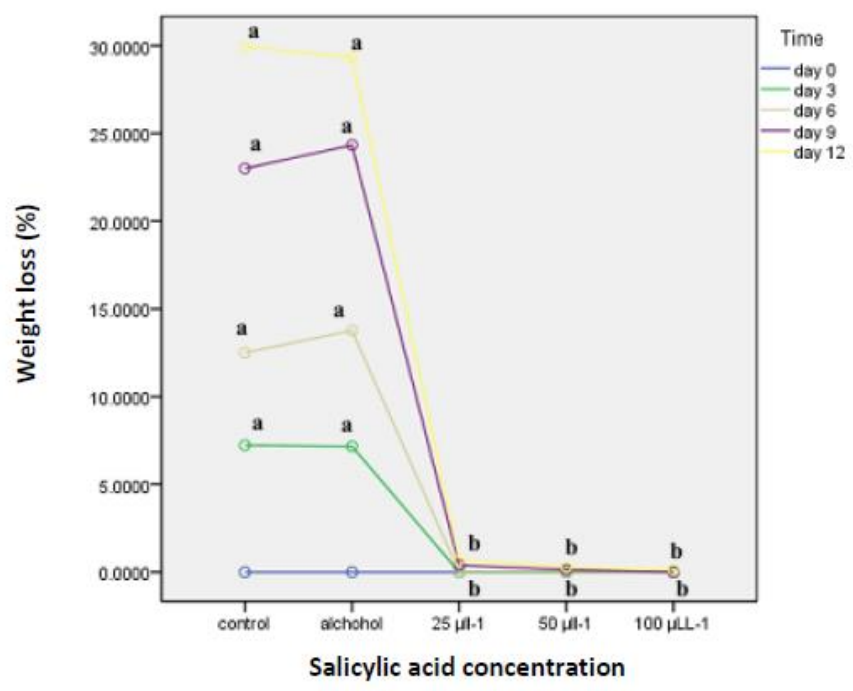

Figure 2. The effect of salicylic acid treatment on weight loss of strawberry fruit in spray method.

\section{$3.2 \mathrm{pH}$}

The $\mathrm{pH}$ value of strawberry fruit increased slightly, corresponding to a decrease in TA during storage. Little difference in $\mathrm{pH}$ value was observed among all of the treatments. Control fruits had the most $\mathrm{pH}$ value and $100 \mu \mathrm{LL}^{-1}$ concentration of SA had the least $\mathrm{pH}$ value (Figure 3). No significant differences were observed between methods of treatments application. Our results are in agreement with Soleimani Aghdam et al. (2011) who found that MeSA treatment significantly affected $\mathrm{pH}$ and $\mathrm{pH}$ of kiwifruit fruit juice increased after 3 months of storage but then decreased to end of storage. The fluctuations of $\mathrm{pH}$ might be due to the variations in TA or temperature of storage and the decline of acidity is attributed due to increased activity of citric acid content may be due to their conversion into sugars and further utilization in metabolic process during storage (Rathore et al., 2007).

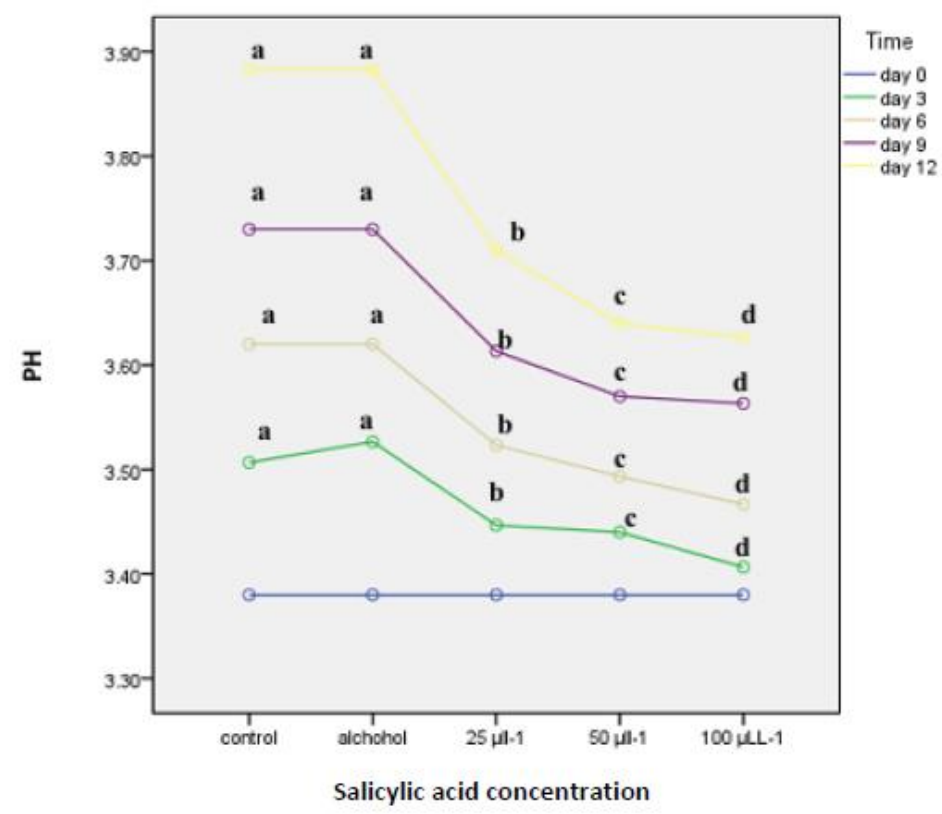

Figure 3 . The effect of salicylic acid treatment on $\mathrm{pH}$ of strawberry fruit. 


\section{Macrothink}

\subsection{TA and TSS Content}

SA treatment increased TA content and decreased TSS content in strawberries compared to controls. TA decreased gradually during storage. TA of $100 \mu \mathrm{LL}^{-1}$ concentration of SA was the highest among all SA concentrations (Figures 4 and 5). TSS of fruits increased during storage. Among all concentrations of SA $25 \mu \mathrm{IL}^{-1}$ had the lowest TSS amount (Figure 6). Fruits that treated with spray method had more TA content compared with paper disk method (Figures 4 and 5). Lolaei et al. (2012) found that postharvest SA treatments induced higher TA values than the control that was in agreement with our results. Lu et al. (2011) reported that postharvest treatment of strawberry with SA resulted in an increased TA of fruit. Also, Bal and Celik (2010) stated that TA content was lower in controls than other treated kiwifruits. TA is directly related to the concentration of organic acid present in the fruit which are an important parameter in maintaining the quality of fruits (Kazemi et al., 2011). Study of Lu et al. (2011) on pineapple fruit showed that the application of SA as postharvest treatment resulted in a decreased TSS. Shafiee et al. (2010) reported that postharvest treatment of strawberry with ASA resulted in a lower TSS than the control. Asghari (2006) reported that SA decreased TSS in strawberry cv. Selva and Lolaei et al. (2012) showed that treatment of kiwifruits with $32 \mathrm{mlL}^{-1} \mathrm{MeSA}$ maintained a lower TSS content than the control fruits at the end of cold storage. These results are in agreement with our results. TSS content of fruits during storage is considered an index of fruit ripening and an increase in TSS of control fruits corresponds to a conversion of starch to soluble sugars.

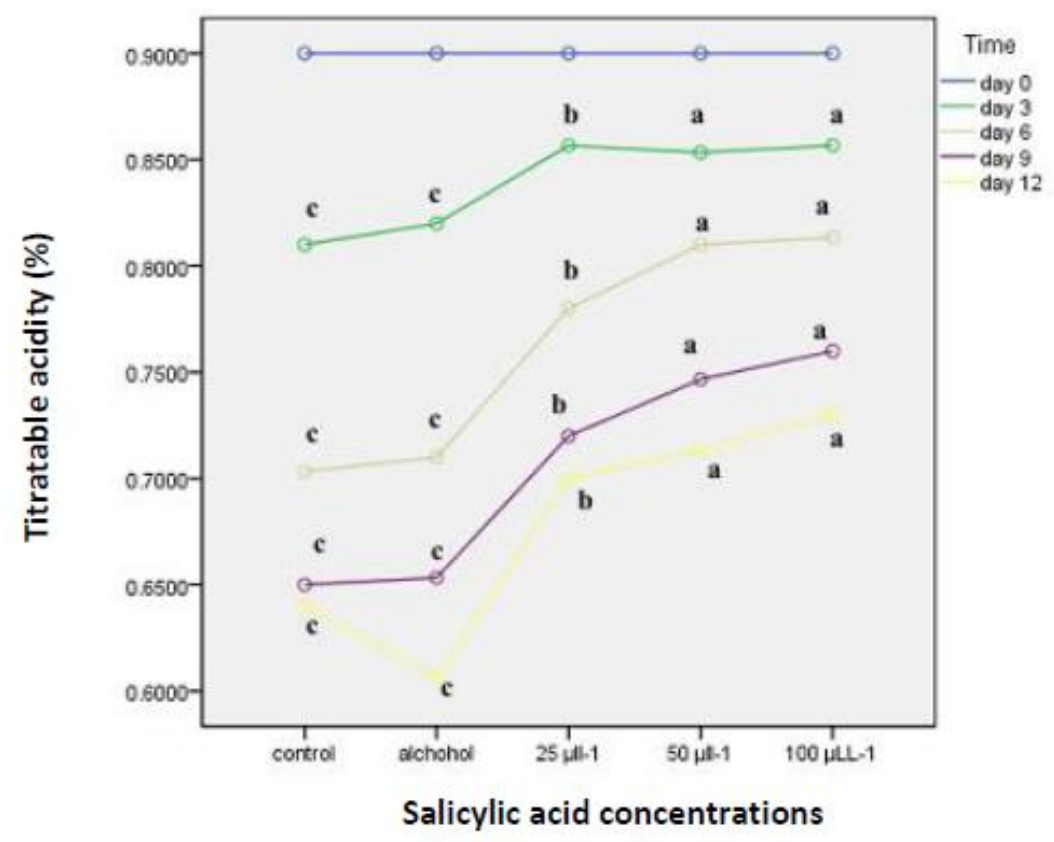

Figure 4. The effect of salicylic acid treatment on titratable acidity of strawberry fruit in paper disk method. 


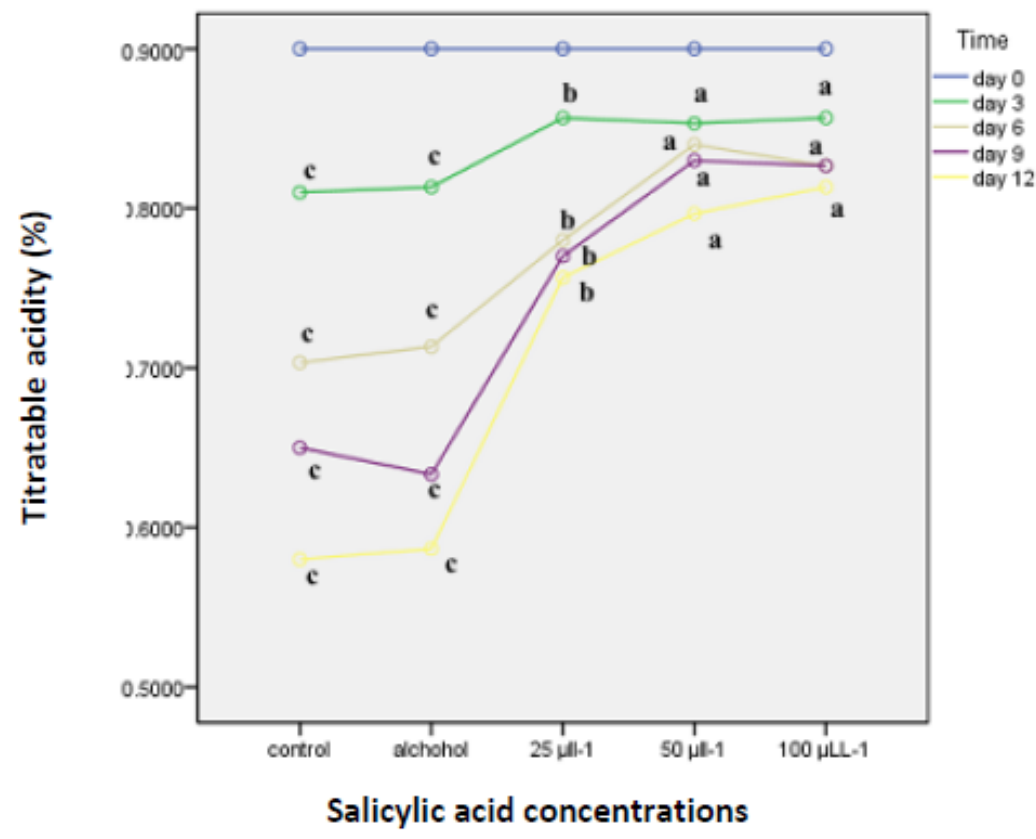

Figure 5. The effect of salicylic acid treatment on titratable acidity of strawberry fruit in spray method.

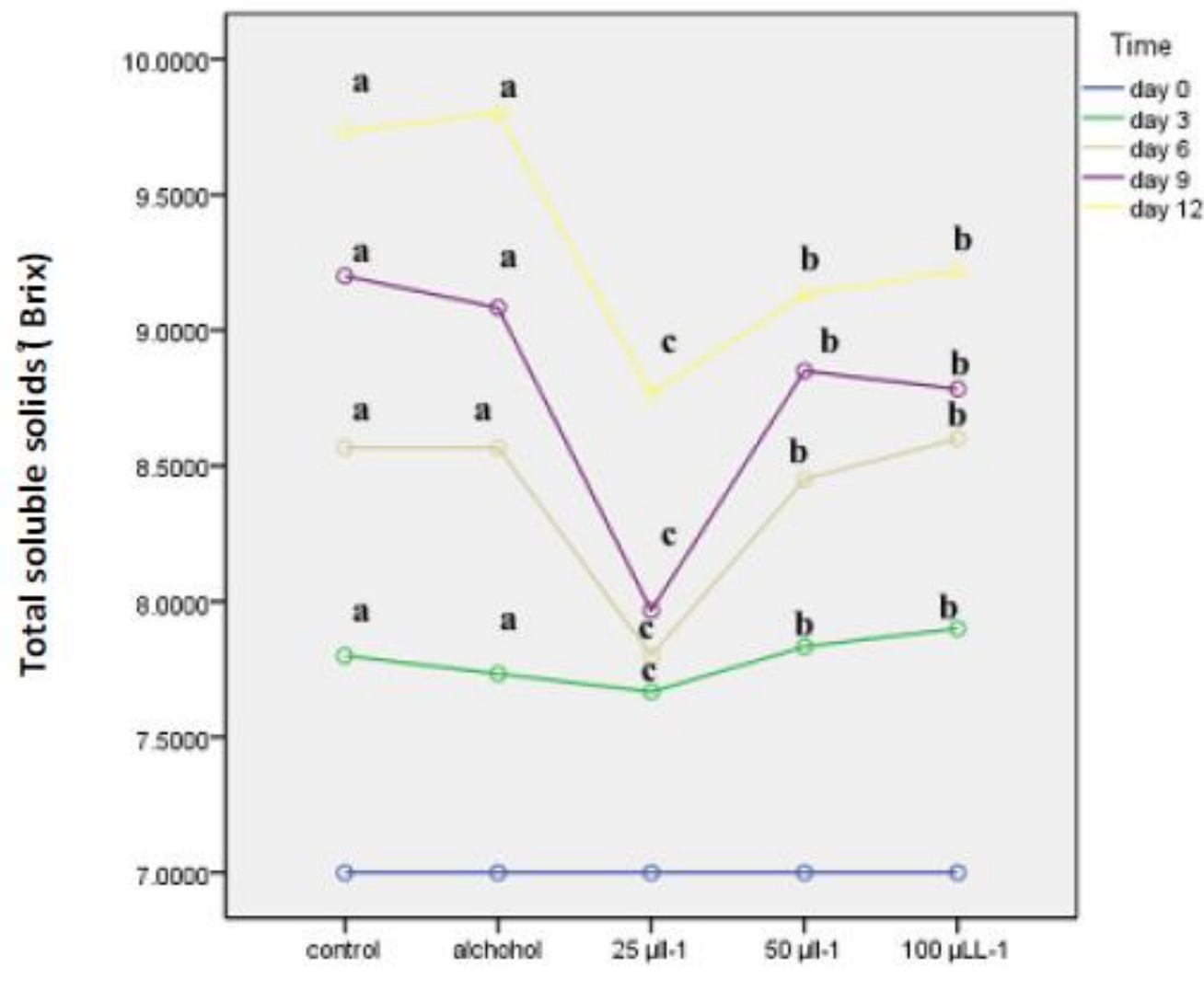

Salicylic acid concentrations

Figure 6. The effect of salicylic acid treatment on total soluble solids of strawberry fruit. 


\section{Macrothink}

\subsection{Vitamin C}

Vitamin $\mathrm{C}$ content of fruits was markedly affected by SA treatment, whereas high concentrations of SA (50 or $100 \mu \mathrm{LL}^{-1}$ ) had the highest amount of vitamin C (Figure 7). The levels of vitamin $\mathrm{C}$ were higher in SA-treated fruits than in control samples. The content of strawberry vitamin C did not show changes in response to SA (Lolaei et al., 2012). The application of SA can increase vitamin $\mathrm{C}$ content and then decrease antioxidant in strawberry fruit (Jing-Hua et al., 2008). Soleimani Aghdam et al. (2011) found that MeSA treatment maintained significantly ascorbic acid content of the kiwifruit during storage and there was a positive correlation between MeSA concentration and fruit ascorbic acid content that are in agreement with our results. Hung et al. (2007) suggested that high ascorbate (AA) contents in the pulp of pretreated fruit with SA may result from an acceleration of biosynthetic pathways or a decrease in catabolism through an accumulation of dehydroascorbate (DHAA).

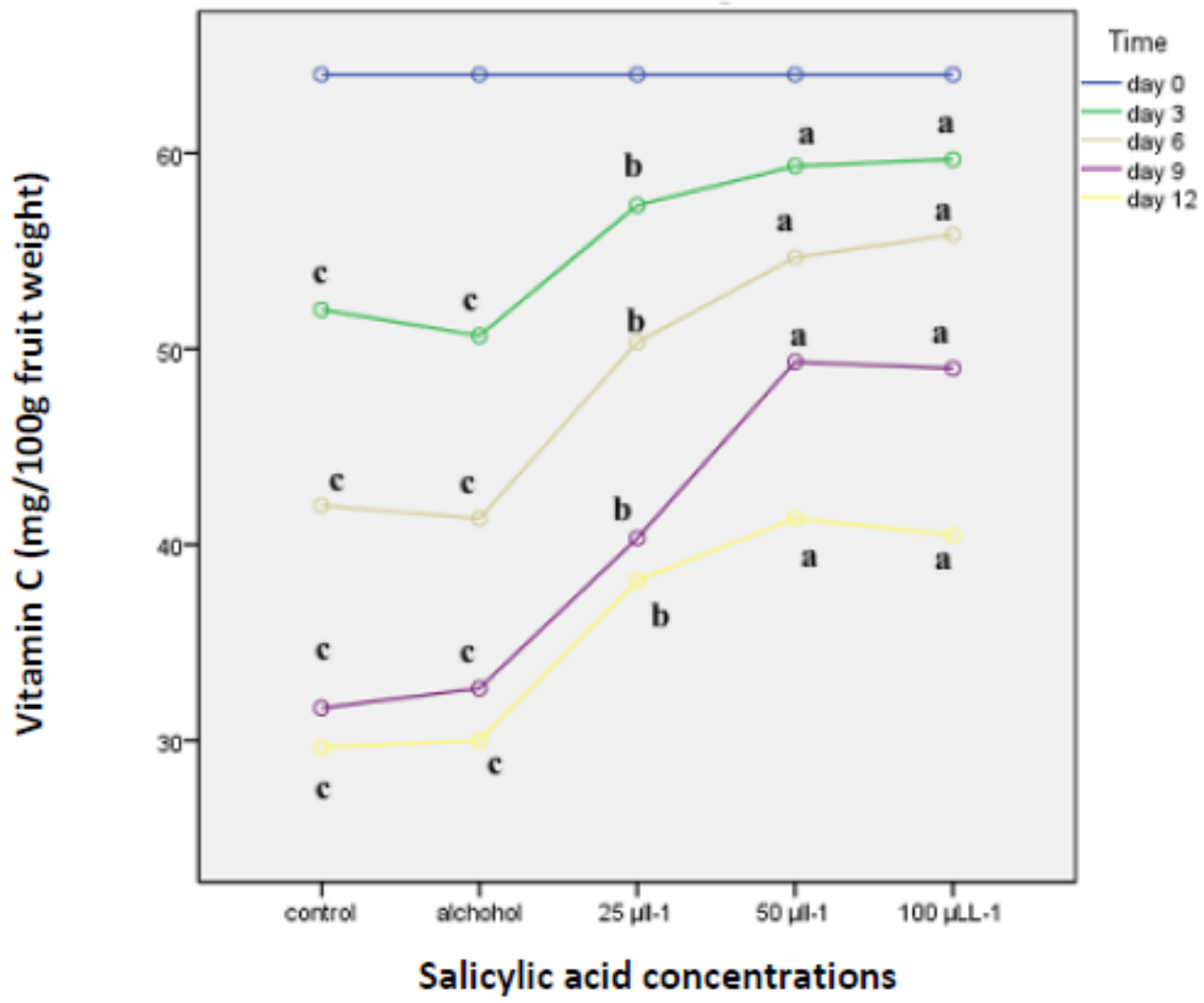

Figure 7 . The effect of salicylic acid treatment on vitamin $\mathrm{C}$ of strawberry fruit.

\subsection{Anthocyanin content}

Anthocyanin content decreased during storage period. As shown in Figure 8, the levels of anthocyanin were higher in SA-treated fruits than in control samples; whereas the higher concentration of SA (100 and $\left.50 \mu \mathrm{LL}^{-1}\right)$ treated fruits had the most amount of anthocyanin. There were not significant differences between two methods of SA application. Anthocyanins are a group of phenolic compounds responsible for the red-blue color of many fruits. Javaheri 


\section{Macrothink}

et al. (2012) stated that application of SA increased the fruit lycopene content also they showed that SA activated the synthesis of carotenoids and xanthophylls. In accordance with our results Tareen et al. (2012) reported that SA treatments significantly affected skin color of peach fruits during 5 weeks of storage period.

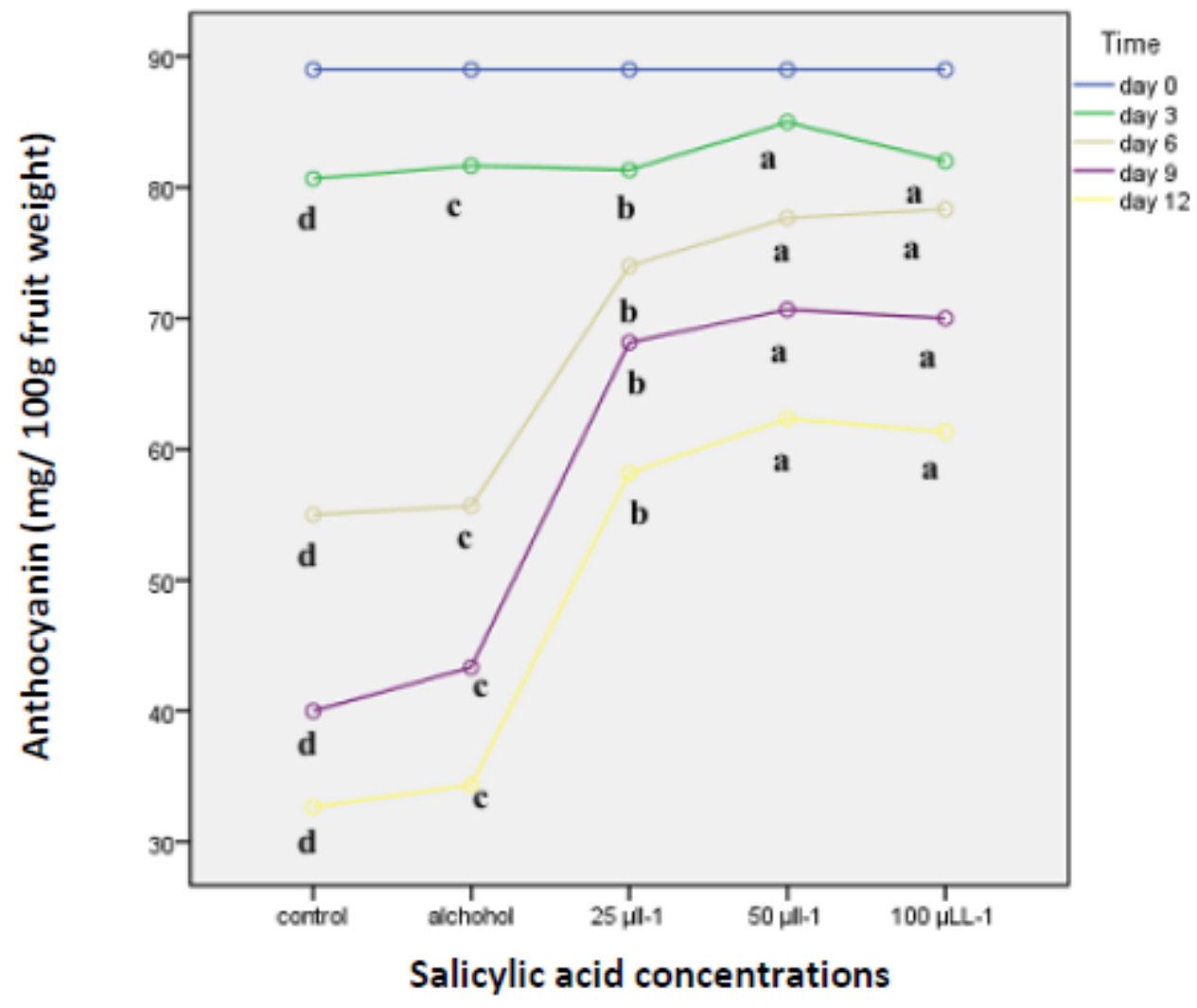

Figure 8 . The effect of salicylic acid treatment on anthocyanin of strawberry fruit.

\subsection{Calcium and Pectin Contents}

Calcium and pectin contents decreased gradually during storage period. SA-treated fruits had more calcium and pectin content compared to controls. There was no significant difference in pectin and calcium between methods of SA application. The effect of SA treatment on fruit calcium and pectin significant varied with the concentrations applied. As shown in Figure 9 and 10 treatment with $50 \mu \mathrm{IL}^{-1}$ had the highest amount of calcium and pectin and the lowest concentration of SA $\left(25 \mu \mathrm{LL}^{-1}\right)$ had the lowest amount of calcium and pectin. Pectins are likely to be the key substances involved in the mechanical strength of the primary cell wall which are important to the physical structure of the plant (Sirisomboon et al., 2000). $\mathrm{Ca}^{+2}$ appears to be necessary because it induces the cross-linking of polygalacturonan chains into a structure that can be recognized by its isoperoxidase (Penel et al., 1999). Coway et al. (1987) stated that the loss of firmness due to call wall carbohydrate metabolism during storage has been associated with increased susceptibility to infection by fungal pathogens. 


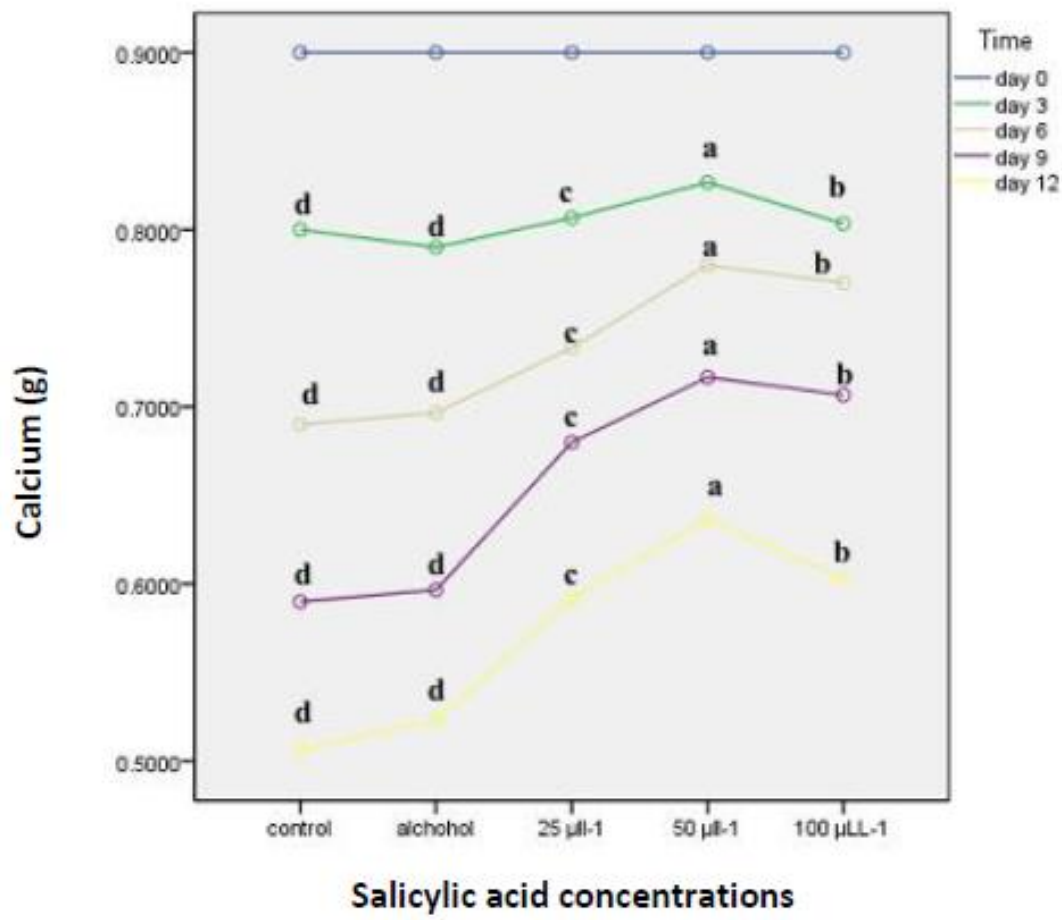

Figure 9. The effect of salicylic acid treatment on calcium of strawberry fruit.

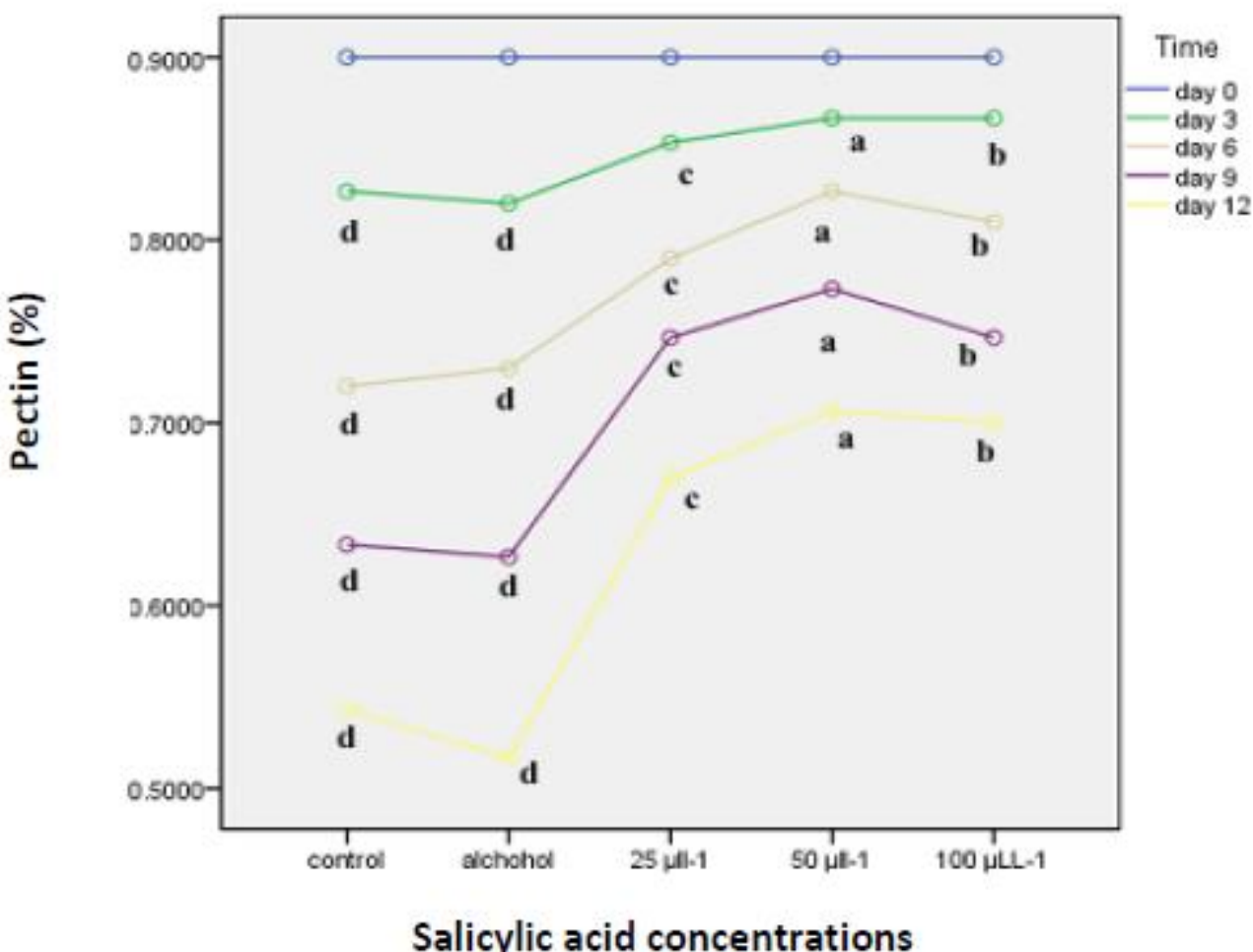

Figure10. The effect of salicylic acid treatment on pectin of strawberry fruit. 


\section{Macrothink}

\subsection{CAT Activity}

Result showed that the catalase activity decreased at the end of the storage period. The samples which were subjected to SA with 50 and $100 \mu \mathrm{lL}^{-1}$ concentrations had the highest catalase activity (Figure 11). Catalase eliminates $\mathrm{H}_{2} \mathrm{O}_{2}$ by breaking it down directly to form water and oxygen. In consistent of our results, Soleimani Aghdam et al. (2011) stated that the lowest CAT activity observed when $32 \mu \mathrm{LL}^{-1}$ MeSA applied at all determination times, while the highest CAT activity was related to control fruits. SA interaction with CAT leads to high levels of $\mathrm{H}_{2} \mathrm{O}_{2}$ accumulation in cells, which induces fruit resistance against pathogens via activating protective enzymes and pathogenesis related (PR) proteins (Klessig and Malamy, 1994; Malamy and Klessig, 1992).

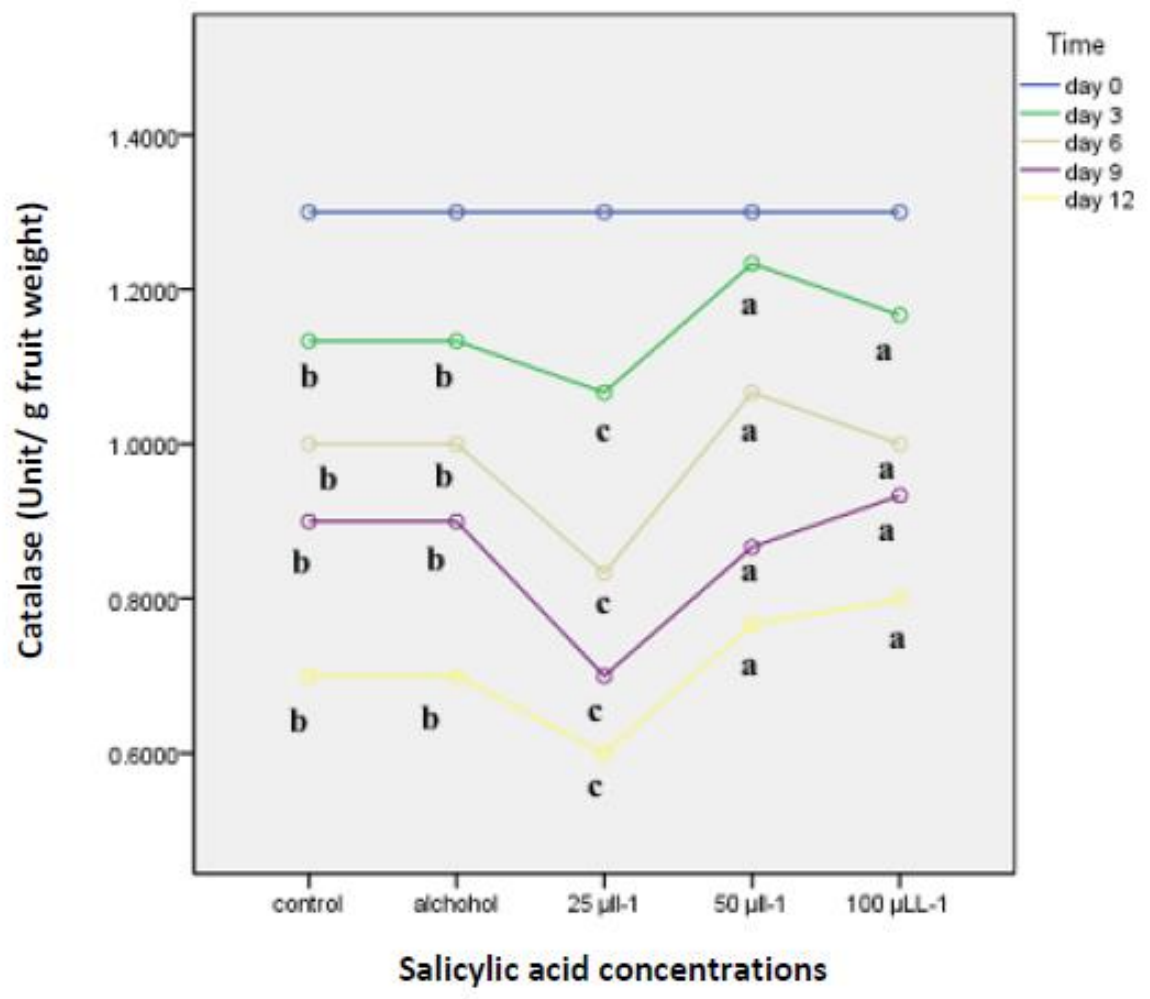

Figure 11 . The effect of salicylic acid treatment on catalase activity of strawberry fruit.

\subsection{POD Activity}

Peroxidase activity increased along the storage. The samples treated with SA concentrations 50 and $100 \mu \mathrm{ll}^{-1}$ showed a significant decreased in POD rate (Figure 12). Peroxidase (POD) activity plays an important role in the oxidative degradation of phenolic compounds, which can lead to the production of brown polymers (Tomás-Barberán and Espín, 2001). Srivastava and Dwivedi (2000) stated that SA treatment decreased levels of POD, than their respective controls, in a concentration dependent manner, during the ripening of banana fruits. In consistent with our results Kazemi et al. (2011) indicated that maximum POD activity was observed in $3 \mathrm{mM}$ SA in the storage duration. 


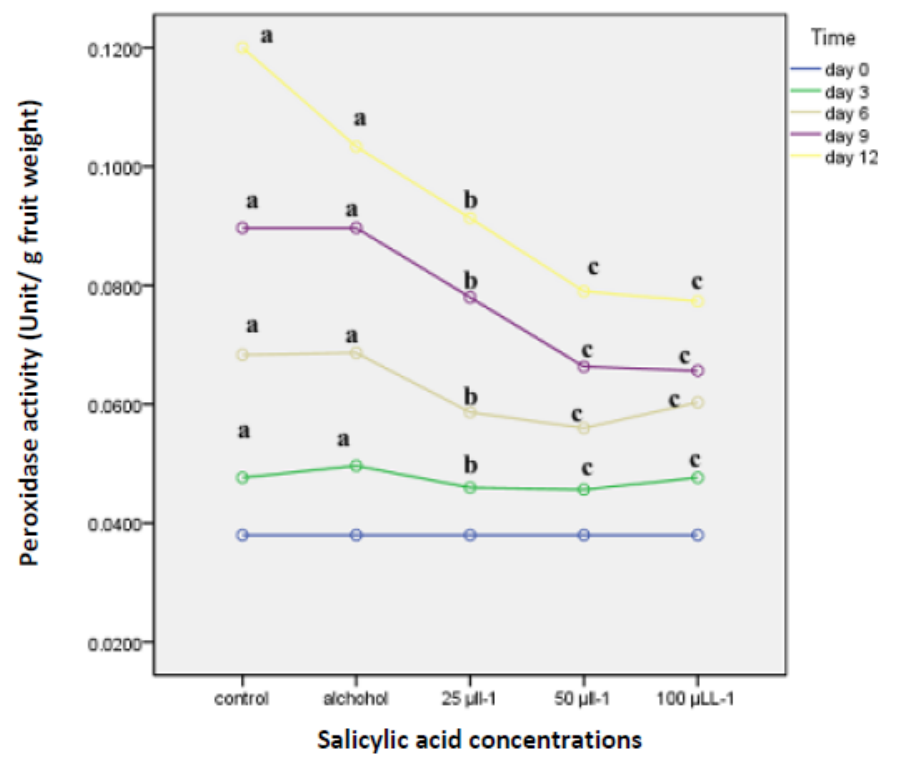

Figure 12 . The effect of salicylic acid treatment on peroxidase activity of strawberry fruit.

\subsection{PG Activity}

PG content of fruits increased significantly along the storage period. The controls had the highest PG activity and the samples which were subjected to SA had less PG activity compared to controls (Figure 13). The samples which were treated with $100 \mu \mathrm{LL}^{-1} \mathrm{SA}$ had the lowest PG activity. Treatment of banana with SA resulted in decreased level of cell wall degrading enzyme in a concentration dependent manner, during the ripening of fruit (Srivastava and Dwivedi, 2000). PG is reported to be primarily responsible for ripening associated pectin degradation and fruit softening (Huber, 1983). Physical and chemical treatments which suppress ripening inhibit PG gene expression (Ogura et al., 1975; Picton et al., 1993).

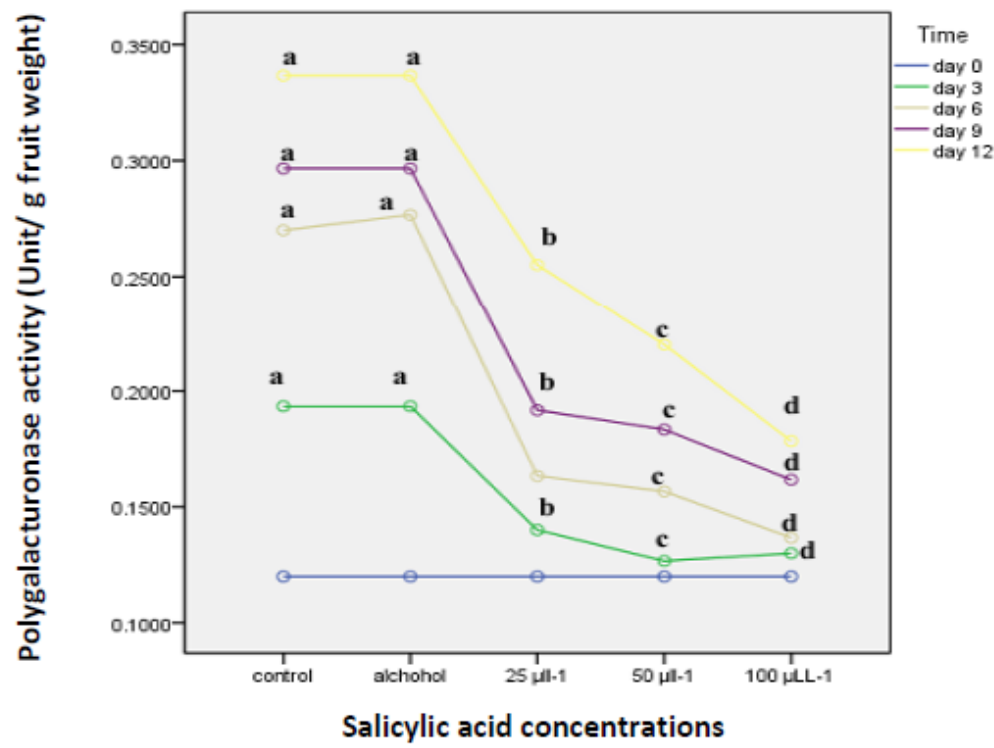

Figure 13. The effect of salicylic acid treatment on polygalacturonase of strawberry fruit. 


\section{Macrothink}

\subsection{Fruit Decay}

The effect of SA treatment on fruit decay significant varied with the concentrations applied and storage time. Treatment with $100 \mu \mathrm{LL}^{-1} \mathrm{SA}$ significantly inhibited fruit decay throughout the storage period, whereas control samples had the least effect. Paper disk method inhibited fruit decay more than spray method (Figures 14 and 15). SA is also involved in local and systemic resistance to fungal pathogens (Meena et al., 2001). It is known that SA can enhance disease resistance of detached plant organs (Meena et al., 2001; Qin et al., 2003). SA can induced disease resistance by coordinate activation of a specific set of PR-genes many of which encode for proteins with antimicrobial activity (Durrant and Dong, 2004; Van Loon et al., 2006). Duan et al. (2007) stated that SA treatment of grapes decreased fungal infections which showed significant differences with control. Soleimani Aghdam et al. (2011) showed that kiwifruit fungal decay was significantly affected by MeSA vapor in the end of shelf life period compared with control fruits. Application of SA in a concentration dependent manner from 1 to $2 \mathrm{mmolL}^{-1}$ effectively reduced fungal decay in 'Selva' strawberry fruit (Babalar et al., 2007). Asghari et al. (2007) found that dipping of pear fruit in $1 \mathrm{mmolL}^{-1} \mathrm{SA}$ solution effectively controlled fruit decay during cold storage period. These results are in agreement with our results.

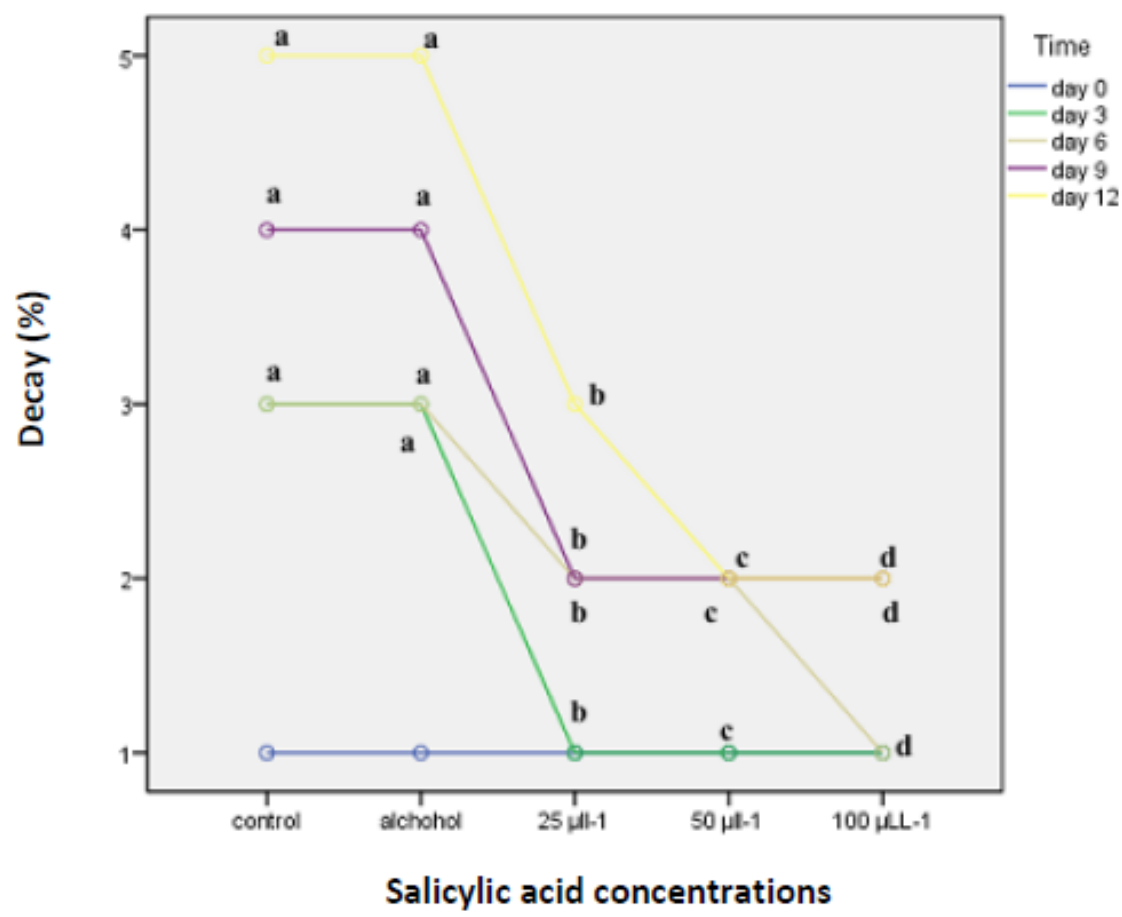

Figure 14. The effect of salicylic acid treatment on decay percentage of strawberry fruit in paper disk method. 


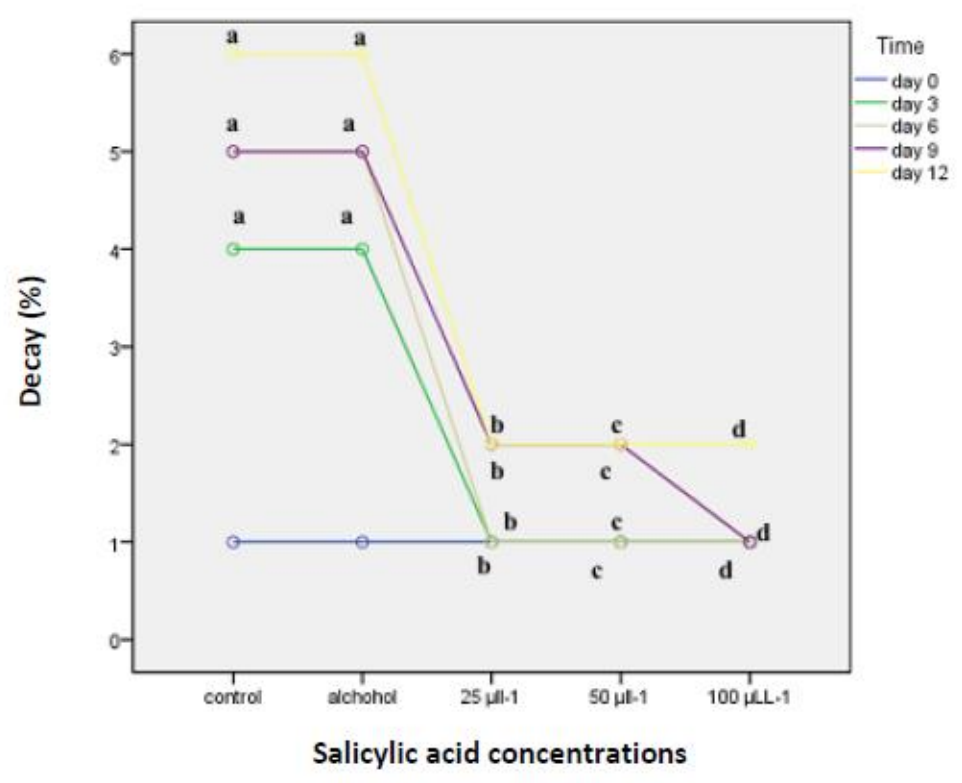

Figure 15 . The effect of salicylic acid treatment on decay percentage of strawberry fruit in spray method.

\subsection{Sensory analyses}

Overall quality decreased continuously during storage at higher rate in untreated fruits compared with those treated with SA. Treatment with $100 \mu \mathrm{LL}^{-1}$ SA had the highest effect on fruit quality among all of concentrations. Fruits that treated with paper disk method had better fruit quality compared with spray method (Figures 16 and 17). These results showed that SA treatment had a significant effect on retaining quality parameters in strawberry fruit. Our results are in accordance with Kazemi et al. (2011) about apple fruit.

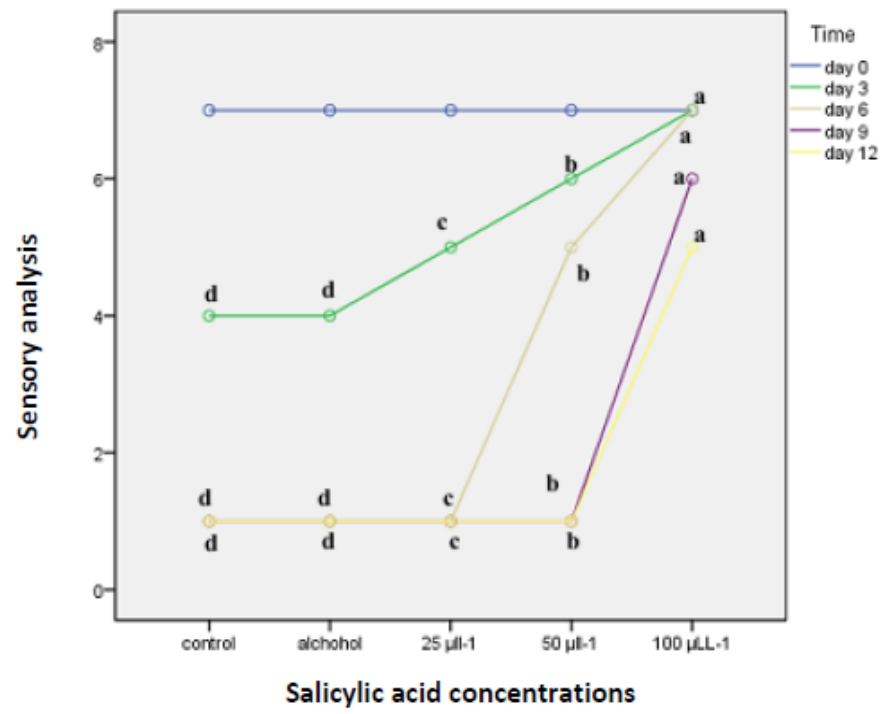

Figure 16. The effect of salicylic acid treatment on sensory analysis of strawberry fruit in paper disk method. 


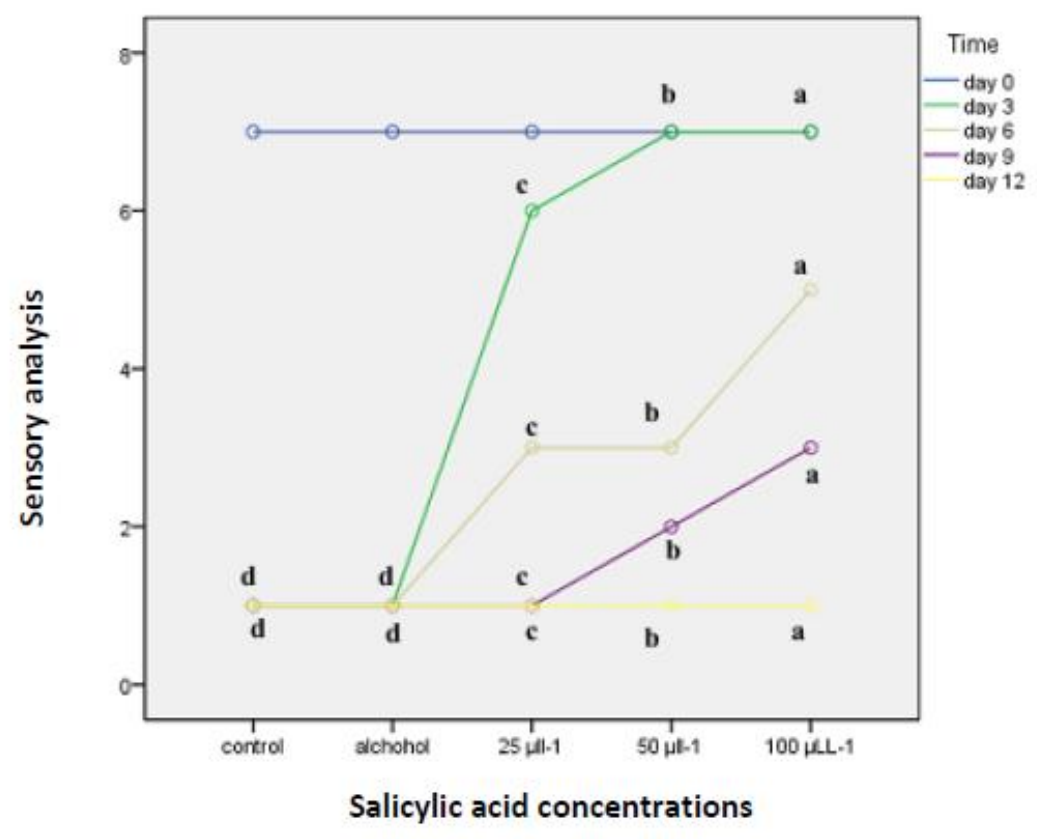

Figure 17. The effect of salicylic acid treatment on sensory analysis of strawberry fruit in spray method.

\section{References}

Aebi, H. (1984). Catalase. In: L. Packer (Ed), methods in enzymology, Academic Press, Orland, 105, 121-126.

Amborabe, B.E., Lessard, P., Chollet, J.F. \& Roblin, G. (2002). Antifungal effects of salicylic acid and other benzoic acid derivatives towards Eutypalata: structure-activity relationship. Plant Physiology and Biochemistry, 40, 1051-1060. http://dx.doi.org/10.1016/S0981-9428(02)01470-5

AOAC, (1990). Official methods of analysis of the Association of Official Analytical Chemists. $15^{\text {th }}$ ed., Association of Official Analytical Chemists, Arlington V A 1058-1059.

Asghari, M.R., Hajitagilo, R. \& Jalil Marandi, R. (2009). Postharvest application of salicylic acid before coating with chitosan affects the pattern of quality changes in table grape during cold storage. In $6^{\text {th }}$ International Postharvest Symposium, Antalya, Turkey.

Asghari, M.R., Hajitagilo, R. \& Shirzad, H. (2007). Postharvest treatment of salicylic acid effectively controls pear fruit diseases and disorders during cold storage. In: Proceedings of the international congress on Novel approaches for the control of postharvest diseases and disorders COST action, 924, 355-360.

Asghari, M. (2006). Effects of salicylic acid on Selva strawberry fruit, antioxidant activity, ethylene production and senescence, fungal contamination and some other quality attributes. Ph.D. Thesis, University of Tehran.

Ayala-Zavala, J. F., Wang, S. Y., Wang, C. Y., \& Gonzalez-Aguilar, G. A. (2005). Methyl 
jasmonate in conjunction with ethanol treatment increases antioxidant capacity, volatile compounds and postharvest life of strawberry fruit. European Food Research Technology, 221, 731-738. http://dx.doi.org/10.1007/s00217-005-0069-z

Babalar, M., Asghari, M., Talaei, A. \& Khosroshahi, A. (2007). Effect of pre and postharvest salicylic acid treatment on ethylene production, fungal decay and overall quality of Selva $\begin{array}{lllll}\text { strawberry fruit. } & \text { Food } & \text { Chemistry, } & \text { 105, } & \end{array}$ http://dx.doi.org/10.1016/j.foodchem.2007.03.021

Bal, E., \& Celik, S. (2010). The effects of postharvest treatments of salicylic acid and potassium permanganate on the storage of kiwifruit. Bulgarian Journal of Agricultural Science, 16(5), 576-584.

Cai, C., Li, X. \& Chen, K. S. (2005). Acetylsalicylic acid alleviates chilling injury of postharvest loquat fruit. European Food Research Technology, 223, 533-539. http://dx.doi.org/10.1007/s00217-005-0233-5

Cheng, G.W. \& Breen, P.J. (1991). Activity of phenylalanine ammonia lyase (PAL) and concentrations of anthocyanins and phenolics in developing strawberry fruit. Journal of American Society Horticultural Sciences, 116, 865-869.

Conway, W. S., Gross, K. C., \& Sams, C. E. (1987). Relationship of bound calcium and inoculums concentration to the effect of postharvest calcium treatment on decay of apples by Penicillium expansum. Plant Disease, 71, 78-80. http://dx.doi.org/10.1094/PD-71-0078

Ding, C. K., Wang, C. Y., Gross, K. C., \& Smith, D. L. (2001). Reduction of chilling injury and transcript accumulation of heat shock protein genes in tomatoes by MeJA and MeSA. Plant Science, 161, 1153-1159. http://dx.doi.org/10.1016/S0168-9452(01)00521-0

Duan, X., Su, X., You, Y., Qu, H., Li, Y., \& Jiang, Y. (2007). Effect of nitric oxide on pericarp browning of harvested longan fruit in relation to phenolic metabolism. Food Chemistry, 104, 571-576. http://dx.doi.org/10.1016/j.foodchem.2006.12.007

Durrant, W. E., \& Dong, X. (2004). Systemic acquired resistance. Annual and Plant Pathology, 31, 139-145. http://dx.doi.org/10.1146/annurev.phyto.42.040803.140421

Fung, R., Wang, C., Smith, D., Gross, K., \& Tian, M. (2004). MeSA and MeJA increase steady-state transcript levels of alternative oxidase and resistance against chilling injury in sweet peppers. Plant Science, 166, 711-719. http://dx.doi.org/10.1016/j.plantsci.2003.11.009

Garcia, J. M., Aguilera, C. \& Albi, M. A. (1995). Postharvest heat treatment on Spanish strawberry. Journal of Agriculture Food Chemistry, 43, 1489-1492. http://dx.doi.org/10.1021/jf00054a014

Hooper, L. \& Cassidy, A. (2006). A review of the health care potential of bioactive compounds. Journal of Science Food Agriculture, 86, 1805-1813. http://dx.doi.org/10.1002/jsfa.2599

Hernandez-Munoz, P., ALmenar, E., Del Valle, V., Velez, D. \& Gavara, R. (2008). Effect of 
chitosan coating combined with postharvest calcium treatment on strawberry quality during $\begin{array}{lllll}\text { refrigerated } & \text { storage. } & \text { Food } & \text { Chemistry, } & 110,\end{array}$ http://dx.doi.org/10.1016/j.foodchem.2008.02.020

Hung, R. H., Liu, J. H., Lu, Y. M., \& Xia, R. X. (2007). Effect of salicylic acid on the antioxidant system in the pulp of Cara Cara navel orange at different storage temperatures. $\begin{array}{lllll}\text { Postharvest Biology } \quad \text { and } & \text { Technology, } & \text { 47, }\end{array}$ http://dx.doi.org/10.1016/j.postharvbio.2007.06.018

Huber, D. (1983). Role of cell wall hydrolases in fruit softening. Horticultural Review, 5, 169-219.

Javaheri, M., Mashayekhi, K., Dadkhah, A., \& Zaker Tavallaee, F. (2012). Effects of salicylic acid on yield and quality characters of tomato fruit (Lycopersicum esculentum Mill.). International Journal of Agriculture and Crop Sciences, 4(16), 1184-1187. http://dx.doi.org/10.1002/9781118060728.ch4

Jing-Hua, Y., Yuan, G., Yan-Man, L., Xiao-Hua, Q. \& Ming-Fang, Z. (2008). Salicylic acid induced enhancement of cold tolerance through activation of antioxidative capacity in watermelon. Science Horticulture, 200-205. http://dx.doi.org/10.1016/j.scienta.2008.06.015

Kazemi, M., Aran, M., \& Zamani, S. (2011). Effect of salicylic acid treatments on quality characteristics of apple fruits during storage. American Journal of Plant Physiology, 6(2), 113-119. http://dx.doi.org/10.3923/ajpp.2011.113.119

Klessig, D. F., \& Malamy, J. (1994). The salicylic acid signal in plants. Plant Molecular Biology, 26, 1439-1458.http://dx.doi.org/10.1007/BF00016484

Lolaei, A., Kaviani, B., Rezai, M. A., Khorrami Rad, M., \& Mohammadipour, R. (2012). Effect of pre and postharvest treatment of salicylic acid on ripening of fruit and overall quality of strawberry fruit. Annals of Biological Research, 3(10), 4680-4684.

Lu, X., Sun, D., Li, Y., Shi, W., \& Sun, G. (2011). Pre and postharvest salicylic acid treatments alleviate internal browning and maintain quality of winter pineapple fruit. Scientia Horticulturae, 130, 97-101. http://dx.doi.org/10.1016/j.scienta.2011.06.017

Mandal, S., Mallick, N., \& Mitra, A. (2009). Salicylic acid acid-induced resistance to Fusarium oxysporum f. sp. Lycopersici in tomato. Plant Physiology Biotechnology, 47, 642-649. http://dx.doi.org/10.1016/j.plaphy.2009.03.001

Miller, G. L. (1959). Use of DNS reagent for determination of reducing sugars. Analytical Chemistry, 31, 426-428. http://dx.doi.org/10.1021/ac60147a030

Malamy, J., \& Klessig, D. F. (1992). Salicylic acid and plant disease resistance. Plant Journal, 2, 643-654. http://dx.doi.org/10.1111/j.1365-313X.1992.tb00133.x

Meena, B., Marimuthu, T., \& Velazhahan, R. (2001). Salicylic acid induces systemic resistance in groundnut against late leaf spot caused by Cercosporidium personatum. Journal 
of Mycology and Plant Pathology, 31, 139-145.

Ogura, N., Nakagawa, H., \& Takenhana, H. (1975). Effect of storage temperature of tomato fruits on changes of their polygalacturonase and pectinesterase activities accompanied with ripening. Journal of Agricultural Chemistry Society Japan, 49, 271-274. http://dx.doi.org/10.1271/nogeikagaku1924.49.271

Penel, C., Van Custem, P., \& Greppin, H. (1999). Interactions of a plant peroxidase with oligogalacturonides in the presence of calcium ions. Phytochemistry, 51, 193-198.http://dx.doi.org/10.1016/S0031-9422(98)00741-9

Peng, L., \& Jiang, Y. (2006). Exogenous salicylic acid inhibits browning of fresh-cut Chinese water chestnut. Food Chemistry, 94, 535-540.http://dx.doi.org/10.1016/j.foodchem.2004.11.047

Picton, S., Barton, S. L., Bouzayen, M., Hamilton, A. J., \& Grierson, D. (1993). Altered fruit ripening and leaf senescence in tomatoes expressing an antisense ethylene forming enzyme transgene. Plant Journal, 3, 469-481.http://dx.doi.org/10.1111/j.1365-313X.1993.tb00167.x

Qin, Q. Z., Tian, S. P., Xu, Y., \& Wan, Y. K. (2003). Enhancement of biocontrol efficacy of antagonistic yeasts by salicylic acid in sweet cherry fruit. Physiology and Molecular Plant Pathology, 62, 147-154. http://dx.doi.org/10.1016/S0885-5765(03)00046-8

Ruck, J.A. (1969). Chemical method of analysis of fruit and vegetable products. Res. Station, Summerland, B.C. 14-16.

Rathore, H. A., Masud, T., Sammi, S. \& Soomro, A. H. (2007). Effect of storage on physio-chemical composition and sensory properties of mango variety Dosehari. Pakistan Journal of Nutrition, 6(2), 143-148. http://dx.doi.org/10.3923/pjn.2007.143.148

Saini, R. S., Sharma, K. D., Kaushik, R. A., \& Dhankhar, O. P. (2006). Laboratory Manual Analytical Techniques in Horticulture. Agrobios (India). IST Edition, pp 12-26.

Shafiee, M., Taghavi, T. S., \& Babalar, M. (2010). Addition of salicylic acid to nutrient solution combined with postharvest treatment (hot water, salicylic acid and calcium dipping) improved postharvest fruit quality of strawberry. Scientia Horticulturae, 124, 40-45. http://dx.doi.org/10.1016/j.scienta.2009.12.004

Sirisomboon, P., Tanaka, M., Fujitha, S., \& Kojima, T. (2000). Relationship between the texture and pectin constituents of Japanese pear. Journal of Text Studies, 31, 679-690. http://dx.doi.org/10.1111/j.1745-4603.2000.tb01028.x

Soleimani Aghdam, M., Motallebiazar, A., Mostofi, Y., Fattahi Moghaddam, J., \& Ghasemnezhad, M. (2011). Methyl salicylate affects the quality of Hayward kiwifruits during storage at low temperature. Journal of Agricultural Science, 3(2), 149-156. http://dx.doi.org/10.5539/jas.v3n2p149

Srivastava, M. K., \& Dwivedi, U. N. (2000). Delayed ripening of banana fruit by salicylic acid. Plant Science, 158(2), 87-96. http://dx.doi.org/10.1016/S0168-9452(00)00304-6 


\section{Macrothink}

Journal of Agricultural Studies

ISSN 2166-0379

2015, Vol. 3, No. 2

Tareen, M. J., Abbasi, N. \& Hafiz, A. (2012). Effect of salicylic acid treatments on storage life of peach fruits cv. 'Flordaking'. Pakistan Journal of Botany, 44(1), 119-124.

Tomás, B. F. A., \& Espin, J. C. (2001). Phenolic compounds and related enzymes as determinants of quality in fruits and vegetables. Journal of Science Food and Agriculture, 81, 853-876. http://dx.doi.org/10.1002/jsfa.885

Van Loon, L. C., Rep, M., \& Pieterse, C. M. J. (2006). Significance of inducible defense-related proteins in infected plants. Annual Review of Phytopathology, 44, 135-162. http://dx.doi.org/10.1146/annurev.phyto.44.070505.143425

Wang, S. Y., \& Zheng, W. (2001). Effects of plant growth temperature and antioxidant capacity in strawberry. Journal of Agricultural and Food Chemistry, 49, 4977-4982. http://dx.doi.org/10.1021/jf0106244

Wang, L., Chena, S., Kong, W., Li, S., \& Archbold, D. D. (2006). Salicylic acid pretreatment alleviates chilling injury and affects the antioxidant system and heat shock proteins of peaches during cold storage. Postharvest Biology and Technology, 41, 244-251. http://dx.doi.org/10.1016/j.postharvbio.2006.04.010

Wills, R., McGlasson, B., Graham, D., \& Joyce, D. (1998). Postharvest, an introduction to the physiology and handling of fruit and vegetables and ornamentals. Sydney 2052, Australia, University of New South Wales Press Ltd., University of New South Wales, 125-156.

Zheng, Y., \& Zhang, Q. (2004). Effects of polyamines and salicylic acid postharvest storage of 'Ponkan' mandarin. Acta Hort, 632, 317-320.

\section{Copyright Disclaimer}

Copyright for this article is retained by the author(s), with first publication rights granted to the journal.

This is an open-access article distributed under the terms and conditions of the Creative Commons Attribution license (http://creativecommons.org/licenses/by/3.0/). 